SVITLANA HLADCHENKO,

National University of Odessa (Ukraine)

e-mail: s.gladchenko@onu.edu.ua, ORCID0000-0001-8802-5111

\title{
MOUNIRA MAYA CHARRAD (new trends in historical science through the prism of personality)
}

\begin{abstract}
In this article, the author analyzes new trends in historical science in the United States, which, during the period indicated in the article, developed on the basis of an interdisciplinary synthesis of existing methods of historical analysis with sociological ones. This trend passes through the prism of the scientific activities of the professor of the Department of Sociology at the University of Texas at Austin, Mounira Maya Sharad, a researcher in the field of political sociology, comparative historical sociology, social theory and gender politics in the countries of the Islamic world. The article contains an analysis of the initial period of the formation of Mounira as a scientist, who is a prominent representative of the postcolonial Tunisian intelligentsia, defines the vector of her scientific search for the traditional social structure of the Tunisian village and the status of Islamic women. Particular attention is paid to the influence of processes in American sociological science on the further professional activities of Mounira Charrad. Since the 1970s last century, historical sociology becomes the main vector of Mounira's study of social phenomena in the countries of the Middle East and North Africa and their typology, first of all, by the methods of comparative analysis, that is, by the method of corporate history.

Mounira Charrad's study of the status of Islamic women was carried out in the context of "women's history", which was a significant area of new social history in the United States. The focus of these studies was on the history of the legal system in the Maghreb countries and the differences between the family law systems of Tunisia, Algeria and Morocco were shown. A qualitatively new stage in the study of women in the Islamic world was Mounira's use of the methodology of gender-historical analysis developed by representatives of the American school of women's history. Mounira Charrad publishes a number of works in which she analyses the evolution and impact of public policy on gender in the Islamic world. The fundamental monograph by Mounira Charad "States and Women's Rights. The Making of Postcolonial Tunisia, Algeria, and Morocco", which has received worldwide recognition among the scientific community, is a comprehensive analysis of the relationship between the state structures of the Maghreb countries with tribal, ethnic formations, primarily in the context of the legal system. The scientific activity of Mounira Charrad reflects the main new trends in American historical science of the last third of the XX - beginning of the XXI century.
\end{abstract}

Key words: Mounira Maya Charrad; Historical Sociology; Gender History; Islamic World.

\section{Introduction}

The leading trend in modern social and humanitarian knowledge is the process of internationalization of historical science. This trend actualizes the need to familiarize domestic humanities scholars with the most significant representatives of the foreign scientific community who have contributed to the formation of a new historical paradigm. This is a French-Tunisian researcher naturalized in the United States.

The range of research interests of Mounira Charrad, Associate Professor of Sociology at the University of Texas at Austin, is wide and interdisciplinary: comparative history, political sociology, social history, gender studies.
The object of study is primarily the Islamic world. Charrad's teaching activities are related to teaching courses in the context of her scientific research. She supervises post-graduate students dealing with topical, littlestudied problems.

\section{Research and Results}

The family had a great influence on the formation of Mounira as a person and a scientist. The mother is French, the father is a Tunisian Arab. Doctors, by education, parents were a vivid example of the new postcolonial intelligentsia of Tunisia, which was characterized by tolerance and democracy. They guided their daughters to 
the need for education in order to gain independence and self-independence. It was her father who instilled in Mounira respect for the poor and the interest in the life and way of life of the Tunisian peasantry.

After graduating from high school in Tunisia, she studied sociology at the Sorbonne, which allowed her to further work at the Center for Social Science Research at the University of Tunis. As Mounira Charrad herself admits, French sociologists and philosophers shaped the scientific atmosphere at the University of Tunis in those years.

Mounira Charrad herself took part in a research project led by renowned French sociologist and anthropologist Jean Duvignaud, who published the book "Shebika: Changes in the Maghrebin Village. Sociological research" (Duvignaud, 1968).

Shebika was one of the poorest regions of Tunisia, and despite this, the young researcher was amazed at the pronounced economic activity of the female population. "I was surprised," writes Sharad, "to discover how independent and strong these women were ... Firstly, they did not hide their faces... and did not correspond to stereotypes about rural women" (Charrad, 2016).

The materials of this field research laid the foundation for a scientific analysis of the specificity of the communal structure of the Tunisian village and increased its interest in the status of women in the traditional environment. The trip also resulted in reports at symposia and conferences.

Another formative research experience for Mounira Charrad was interviewing of local politicians in Cap Bon, a coastal region to the east of the Tunisian capital. These studies revealed the contradictions between the development of centralized state institutions and associations in local societies - a problem to which she will return in her later research.

Note that since the 1960 s, sociology as an integrative interdisciplinary science has become especially popular and the United States has undoubtedly become the center of sociological research. Mounira Charrad's admission to graduate school in sociology at Harvard allowed her to engage in scientific activities actively. She continued to engage in field research with grants from the Smithsonian Institution and Stanford University, and led the project "Education, employment and fertility in Tunisia" from 1974-1975s.

While attending Harvard, she was elected, as a PhD student representative to faculty meetings, and colloquium coordinator. This position gave her the opportunity to meet a wide range of eminent sociologists from several universities in the country and around the world. For example, under the guidance of the prominent American scientist, the creator of the modern theory of sociology and widely known to domestic researchers of the theory of modernization, Professor Talcott Parsonson, for several years she was engaged in sociological research of graduates of Harvard University. At the same time, attention to the problems of the Islamic world was expressed in the writing of a work on family structure in the Middle East.

By the early 1970s, the United States was actually becoming a center for the study of historical sociology. In addition to the above stories, this was largely facilitated by the publication of the book by the American sociologist Barrington Moore "The Social Origins of Dictatorship and
Democracy." This study produced a worldview revolution in both American and Western sociology, the content of which actually denied the linear progressive concept of history and, accordingly, the classical theory of modernization. Barrington Moore asserted the variability of the transition from a traditional agrarian society to a modern urban one (Barrington Moore, 2016). Mounira Charrad studied with Barrington Moore, was a listener of his seminar "Class and Politics", which was very popular among the graduate students, presented by the rigorous methodology of comparative history. As Mounira Charrad herself notes, it was the methodological basis that later found application in her scientific activities. We are talking about the study of social phenomena in the countries of the Middle East and North Africa and their typology, primarily by methods of comparative analysis, i.e. about comparative history. From this point on, historical sociology became the main vector of Mounira Charrad's scientific research.

In the 1970s, a new historical discipline was developing in the United States: women's history. Without abandoning interdisciplinary methods and general concepts of the "new social history", "women's history" also applies its own specific categories and concepts. Integrating various research approaches, its representatives set the task of restoring the integrity of the "new social history" by including women in it. The subject of attention of the "history of women" is a wide range of problems associated with the past of women, including those subjects that were the subject of study of related disciplines: demographic history, family history, anthropology, etc. At the same time, the main research perspective associated with "history from below", "folk history" was not lost. Mounira Charrad was also actively included in this trend. In 1976, in a special series of monographs from the Smithsonian Institution (Washington), she published "The Impact of Employment on Birth Control in Tunisia" (Charrad, 1976). Charrad's dissertation research focused on the history of family law in Tunisia, Algeria and Morocco, highlighting the differences in family law in the three countries. The scientific adviser to the doctoral student was the outstanding American sociologist Seymour Martin Lipset, whose scientific interest was determined by the study of the historical paths of transition to democracy. Note, In the obituary dedicated to Lipset, the British newspaper "The Guardian" called him "the leading theorist of democracy and American exceptionalism" ("the leading theorist of democracy and American exceptionalism") (McGovern, 2010).

However, in the future, a closer and more fruitful scientific collaboration developed between Mounira Charrad and the future famous sociologist Ann Swidler, the author of one of the most cited works on sociology, "Culture in Action: Symbols and Strategies" (1986), which argues that sociocultural specificity determines behavior in society (Swidler, 1986).

In 1980, Mounira Charrad graduated from Harvard with a doctorate in sociology and published reviews and reviews of a number of monographs on various aspects of women's history in the Arab world. First of all, it should be mention of the moderate criticism of the work of the feminist Fatna A. Sabbah, written in a postmodern vein and dedicated to the perception of women in the subconscious of Muslims. (Sabbah, 1984) And review articles on 
the problems of the legal status of women in the Islamic world (Charrad, 1982; 1986).

In the 1980s, as a result of the theoretical rethinking of the subject of research by the representatives of the American school of women's history, gender history was born. The development of the methodology of genderhistorical analysis was determined by the representative factual material of specific studies, which showed, on the one hand, the diverse role of women in economic and political intellectual processes. On the other hand, the contradictory impact of these processes on their lives. In addition, a significant differentiation of individual and collective experience was revealed, resulting from the intersection of class, gender, social, ethnic, and confessional divisions. It is the latter aspect that has made the study of gender relations in the Islamic world actual. Mounira Charrad's first work on gender issues was published in 1997s under the title "Political Shifts: State, Islam and Gender in Tunisia, 1930 - 1990s ". In this monographic article, the author analyzes the evolution and influence of public policy on the gender situation in Tunisian society. The article provides a comparative analysis of four political situations: nationalism under colonial rule in the 1930 s, the formation of a nation-state in the 1950s, consolidation of the state in the 1970s, and the state that was challenged by feminism and Islamic fundamentalism in the 1990 years.

Mounira Charrad focuses on the fact that during the national liberation movement against French rule, the problem of women's rights was practically not solved. During the republican period, the problem of women's rights was a kind of "trump card" in the struggle of the secular state against the opposition Islamic movements. The author emphasizes that only in the 1990s, defenders of women's rights, thanks to their participation in the political struggle, were able to achieve certain positive results. At the same time, she admits that despite the weakness of civil society, by the mid-1990s. in Tunisia, the participation of women in public life and the government increased.

A decade of intense scientific research was embodied by Mounira Charrad in the first monograph "States and the rights of women: the creation of postcolonial Tunisia, Algeria and Morocco" in 2001s, in which not only previous publications were summarized, but new historical sources were used, primarily related to the colonial period and Islamic law (Charrad, 2001). In the monograph, the emphasis is shifted to the relationship of state structures of the Maghreb countries with tribal, ethnic formations, primarily in the context of the legal system. At the same time, M. Charrad emphasizes that many researchers do not understand the essence of social processes in Islamic societies, since they do not take into account the importance of tribal social organization, which contrasts with the traditional European class-oriented model. The content of the study organically leads to the conclusion that customary law and the tribal system affect the position of women in the post-colonial countries of the Maghreb, as before. Mounira Charrad, on the basis of a fairly detailed comparative analysis of the political realities of the postcolonial countries of the Maghreb, explains why in the post-colonial period women in Tunisia, even in the absence of a feminist movement, received broad legal rights. While, despite a certain commonality of socio- cultural traditions of the Maghreb countries, women in Algeria and Morocco remained legally deprived of rights. After gaining independence, the central authorities of these countries decided to adopt legislation corresponding to the Maliki school of Islamic law and preserved the interests of clan structures and the dominance of men. In the work, in a gender context, presents an analysis of the sources of the Maliki law school and the author concludes that the subordinate status of women is one of the most obvious and distinctive features of these documents.

The author emphasizes that a different situation has developed in Tunisia. In Tunisian society, even before the beginning of the colonial period, a unified system of family law was formed, and tribal and independent religious formations were weaker in comparison with Algeria and Morocco, which was a prerequisite for the creation of the adoption by the Tunisian leadership of progressive and modern-day family law legislation. The Tunisian Personal Status Code largely sanctioned the nuclear family model and expanded the rights of women. The promulgation of the Personal Status Code has fundamentally changed family law and the legal status of women. The provisions on marriage, divorce, alimony, custody, adoption and inheritance were changed. The Code, through numerous revisions, gave priority in the right of inheritance to children (men or women) over other relatives, even if they were men. The code also prohibits polygamy, allows women to file for divorce on the same grounds as men, gives mothers the same custody rights as fathers, and places men and women in the same position with respect to adultery committed by a husband or a wife became considered as a crime punishable by a fine and imprisonment. It should be noted that the author repeatedly emphasizes the importance of the adoption of these laws and the leading role of Tunisia in the Maghreb. We emphasize that the above-mentioned monograph by Mounira Charrad has received worldwide recognition among the scientific community. The concept of the book is focused on the kinship and ethnicity of the region and move away from an understanding of politics based on a religious approach.

The above review of the monograph is determined by the fact that its publication has become a landmark event for gender history. This research has been translated into French, Arabic, Chinese. The scientific merit is judged by the number of awards this book has received. Two awards from the American Sociological Association, the American Political Science Association and the Eastern Sociological Society, and the Best Monograph in History Award from the International Honorary Society Phi Alpha Theta, the Sociology Komarosvky Award.

Undoubtedly, the further scientific activity of Mounira Charrad was mainly associated with gender problems, and articles are published on various aspects of this history of Tunisian society. This attention to the historical homeland resonated with the scientific community of Tunisia and in 2005s Charrad was awarded the Ibn Khaldun Prize for "a the best understanding of Tunisian society, history and culture."

We emphasize that in the past two decades, in the context of historical comparative studies, Mounira Charrad's scientific interest has practically covered the entire Islamic world, and covered a number of problems: the role of Islam in the formation of modern social struc- 
tures and statehood, the evolution of gender relations. Undoubted merit of the researcher in the recognition that "modernization" is not adequate to the concept of "secularization" and the realities of modernity in the countries of the Islamic world are formed not only in the process of opposition to the Islamic tradition, but also as a result of their adaptation to new historical conditions (Charrad, 2015).

Charrad's research actually confirms the concept of the "plurality of modernity", which has become a modern alternative to the classical European paradigm of modernization. Its founder, Shmuel Eisenstadt, argued that modernization is not identical with Westernization and the sociocultural specificity largely determines the variability of this process. Without denying the universal essence of modernization, he, at the same time, recognizes its many cultural and historical variants (Charrad, 2011). The concept of the "plurality of modernity" has found quite a few supporters. So in the works of modern Chinese researchers, an analysis of the essence of the East Asian model of modernity and the significance of the experience of the East Asian model of modernization are presented (Chernikh, Gladchenko, 2018).

\section{Conclusions}

The content of Mounira Charrad's works corresponds to new trends in historical science, which are determined by a reassessment of the role of tradition in the process of modernization, an awareness of the importance of studying non-Western societies, in this case, the Islamic world, and an understanding that this study is necessary not only as knowledge of regional historical experience, but as rethinking the history of the modern world as a whole. And this rethinking is not based on linear progressivism and evaluative binary oppositions: East-West, tradition-innovation, religious-secular, female-male and is determined by a new type of rationality.

Characterization of socio-cultural determinants of gender value orientations and stereotypes of behaviour that have developed in the context of the Islamic world, their interaction or opposition with the realities of our time is today the main direction of Charrad's scientific research.

In conclusion, we note that the internationalization and interdisciplinarity characteristic of American historical science deserve attention and special research on the part of Ukrainian scientists, as a positive experience of gaining new prospects for scientific research.

\section{REFERENCES}

Charrad M., Suzman R., Miller K. (1976). Employment Effects on Fertility Control in Tunisia. In: Recent Empirical Findings on Fertility: Korea, Nigeria, Tunisia, Venezuela, Philippines. Smithsonian Institution, Washington, D.C.

Charrad, M. (1982) "Review" of Women in Muslim Family Law by J. L. Esposito. Sociological Analysis, 43 (4): 389391.

Charrad, M. (1986). "Review" of Woman in the Muslim Unconscious by Fatna A. Sabbah. Middle East Studies Association Bulletin. 20 (2): 191-192.

Charrad, M. (2001). States and Women's Rights. The Making of Postcolonial Tunisia, Algeria, and Morocco. Berkeley, CA: University of California Press.

Charrad, M (2011). Gender in the Middle East: Islam, State, Agency. Annual Review of Sociology. 37: 417-437 doi: https://doi.org/10.1146/annurev.soc.012809.102554

Charrad, M. (2016). Living History Interview. The Journal of Gender, Race, and Justice. 18(2), 457-476

Charrad, M.\& Jaster, D. (2015). Limits of Empire: The French Colonial State and Local Patrimonialism in North Africa. Patrimonial Capitalism and Empire. Political Power and Social Theory, Vol. 28., Emerald Group Publishing Limited, 63-89. doi: https://doi.org/10.1108/S0198871920150000028003

Chernikh, I., Gladchenko, S. (2018). Teoriya modernizatsiyi ta realiyi afro-aziat-skoyi modernizatsiyi (sotsiokul'turnyy rakurs). Gileya. 130 (3): 151-154.

Duvignaud, J. (1968). Chebika: Mutations dans un village du Maghreb. Étude sociologique. GALLIMARD; French Language Edition.

McGovern, Patrick (2010). The young Lipset on the iron law of oligarchy: a taste of things to come1. The British Journal of Sociology. 61 (Suppl 1): 29-42. doi:10.1111/j.1468-4446.2009.01283.x.

Mur, Barrington. (2016). Sotsialnyye istoki diktatury $i$ demokratii: rol pomeshchika $i$ krest'yanina $v$ sozdanii sovremennogo mira [Translat. drom Engl.]. Moscow: Vyshaya shkola ekonomiki. (In Russian)

Sabbah, F. (1984). Woman in the Muslim Unconscious. Pergamon

Swidler, A. (1986). Culture in Action: Symbols and Strategies. American Sociological Review. 51 (2): 273-286. doi: https://doi.org/10.2307/2095521

\section{Світлана Гладченко,}

Одеський національний університет імені I.I.Мечникова (Украӥна)

e-mail: s.gladchenko@onu.edu.ua,ORCID0000-0001-8802-5111

\section{Муніра МАЙЯ ЧАРРАД (нові тенденції в історичній научі крізь призму особистості)}

У статті автор аналізує нові тенденції історичної науки крізь призму наукової діяльності професора кафедри соціології Техаського університету в Остіні Муніри Майї Чаррад, дослідниці в області політичної соціології, порівняльно-історичної соціології, соціальної теорії та гендерної політики в країнах ісламського світу. Стаття містить аналіз початкового періоду становлення Муніри як вченого, що є яскравою представницею постколоніальної туніської інтелігенції, визначається вектор її наукового пошуку традиційної соціальної структури туніського села і статусу ісламських жінок. Особлива увага приділяється впливу процесів в американській соціологічній науці на подальшу професійну діяльність Муніри Чаррад. 3 70-x pp. XX століття історична соціологія стає основним вектором вивчення Мунірою соціальних феноменів в країнах Близького Сходу і Північній Африці і їх типологізації, перш за все, методами порівня- 
льного аналізу, тобто методом корпоративної історії. Доведено, що якісно новим етапом вивчення жінок ісламського світу стало використання Мунірою методології гендерно-історичного аналізу, виробленої представниками американської школи жіночої історії. Дослідниця публікує ряд робіт, в яких аналізує еволюцію і вплив державної політики на гендерну ситуацію в країнах ісламського світу. Фундаментальна монографія Муніри Чаррад «Держави і права жінок: створення постколоніального Туніса, Алжира і Марокко» здобула світове визнання в науковому середовищі, являє собою комплексний аналіз взаємин державних структур країн Магрибу з племінними, етнічними утвореннями, в першу чергу в контексті системи права. Наукова діяльність Муніри Чаррад відображає основні нові тенденції в американській історичній науці останньої третини XX-початок XXI століття.

Ключові слова: Муніра Майя Чаррад; історична соціологія; гендерна історія; ісламський світ.

(C) Svitlana Hladchenko

Надійшла до редакції: 19.09.2020

Прийнята до друку: 07.11.2020 